\title{
Osmanlı’da Ticarî Yol Sistemi ve Taşımacılık: Konya Örneği(1700-1750) ${ }^{1}$
}

\author{
Rümeysa Kars ${ }^{2}$ \\ Nevşehir Haci Bektaş Veli University, Assistant Professor, Faculty of Arts and Sciences, \\ Nevşehir, Turkey \\ Received- Accepted: 26.06.019-22.08.2019 \\ Research Article
}

$\ddot{\mathbf{O z}}$

Konya, gerek konumu ve gerekse transit ticaretin bir geçiş merkezi olması hasebiyle tarihî süreçte geniş halk kitlelerinin ve tacir erbabının dikkatini çekmiştir. Konya, bir şehir merkezi olarak Osmanlı idaresinde de önemini korumuş ve bir kültür, ticaret ve sanayi şehri olma özelliğini muhafaza edebilmiştir. Ancak bölge, Osmanlı Devleti’nde hayvancılık bakımından eskiden beri daha önemli bir merkez olarak kabul görmüşür. Çünkü kent, ordunun sefer güzergâhında bulunmaktaydı ve bu bölge halkının bir kısmı ordunun ihtiyacı olan atlanı geniş bozkırlarda yetiştirmekteydi. Bunun yanında kervan ticareti de kara yolu taşımacılığını öngördüğünden ve tarihî ipek yolunun bir kolu da bu güzergâhtan geçtiği için bizzat tüccar taifesi de Konya'ya uğradığında eşyalarının nakli hususunda yöre halkından bu taşıma hayvanlarını kiralamak hatta satın almak suretiyle temin edebilmekteydiler. Bu ihtiyaç hem kente ekonomik bir katkı sağlamakta hem de kente farklı noktalardan tüccarların uğramasına imkân sağlamaktaydı. Ayrıca kent hac güzergâhında bulunuyor ve hicaz ticaretinden de pay alıyordu. Kentte mevcut ticarî yol ağı ve ulaşım şartlarının hangi taşımacılık esasına göre tertip edildiğini tespit edebilmek amacıyla 18 . yüzyıl temelinde ele alınan döneme ilişkin bu çalışmada Şer’iyye sicilleri temelinde kaynak kitap ve makalelerden istifade edilmiştir.

Anahtar Kelimeler: Konya, Ticaret, Ulaşım, Taşımacılık, Şer'iyye Sicilleri.

\section{The Commercial Road System and Transportation in Ottoman: Konya Sample (1700-1750)}

\begin{abstract}
Because of its location and transit trade, Konya has attracted the attention of the wider public and traders. As a city center, Konya maintained its importance in the Ottoman administration and was able to maintain its status as a cultural, commercial and industrial city. However, the region has been accepted as a more important center in terms of animal husbandry in the Ottoman Empire. Because the city was located on the expedition of the army and some of the people of this region were raising the horses that the army needed in the vast steppes. In addition, since the caravan trade also foresees road transport and a branch of the historical silk road passes through this route, when the merchant cargo stopped by Konya, they were able to rent and transport these transport animals from the local people even when they had to go to Konya. This need not only made an economic contribution to the city, but also allowed traders from different locations to come to the city. In addition, the city was on the pilgrimage route and it also took part in the trade of hijaz. In order to determine the commercial road network and transportation conditions in the city on the basis of the transportation basis, in this study on the basis of the 18th century, source books and articles were used on the basis of Şer'iyye registers.
\end{abstract}

Keywords: Konya, Trade, Transport, Transportation, Şer'iye Registers.

\footnotetext{
${ }^{1}$ This article is analyzed by three reviewers and it is screened for the resembalance rate by the editor. (Bu makale üç hakem tarafindan incelenmiş ve editör tarafindan benzerlik oranı taramasından geçirilmiştir)

${ }^{2}$ rumeysakars@nevsehir.edu.tr, ORCID:0000-0001-5176-1107
} 


\section{Giriş}

Şehirlerin doğuşu ve gelişiminde coğrafî yapının önemli bir rolü vardır. Mekân şartlarının müsait olduğu stratejik noktalarda tarih boyunca şehirlerin doğuşuna tanık oluyoruz. Konya, ticaret yolları güzergâhında, Anadolu'nun elverişli iklim koşullarına sahip bir mevkide yer almaktaydı. Kentin muhkem yapısı ve giriş kapılarının çevresi, birer sanat ve ticaret bölgesi haline gelmiş, açlan dükkanlar ile buralarda çarşılar oluşmuştu. Özer Ergenç'in ifadeleriyle kentin giriş kapılarn; Şehrin güneyinde Sahip Ata Külliyesi’nin yaknında yer alan kapı, Larende(Karaman) Kapısı idi. Bugünkü Kapıcamii ve Aziziye Camileri’nin arasında yer alan At Pazarı Kapısı, şehrin civarındaki köy yolları ile bağlantılı idi. Mevlana Külliyesi nin yakınındaki Aksaray Kapısı, adını Konya'y Aksaray ve Kayseri’ye bağlayan yoldan almuşt. Şehrin batı ve kuzeybatısındaki kapılar, Akşsehir üzerinden Antalya ve İstanbul yönüne uzanan yolların çılkş yerleri idi. Şehrin civarındaki bă̆larla Sille ve Meram gibi mesire yerleri ile bağlantı da buralardan sağlanıyordu. (Ergenç, 2012,s. 32)

Bu giriş noktalarının ticarî önemi İslâm şehirlerinde bir karakteristik özelliktir. (Barthold, 1984,s.24) Bunun iki nedeni olmalıdır: Birincisi şehre gelenlerin (civar köyler ahalisinin, yabancı tüccarların) kolayca uğrayabilecekleri yer oluşu; ikincisi de buraların özel bekçiler tarafindan korunduğu için güvenilir alanları teşkil etmesidir. (Ergenç,s.33) Bu konuda 1766'da matematikçi ve topograf olan Carsten Niebuhr adlı Alman bir gezgin Halep’ten Konya'ya geldiğinde kervanda Rum yolcuların da olduğunu belirterek şehrin plânını betimlemiştir. Şöyle ki, Konya’nın 7 giriş kapısı var: Pazar kapısı, Yeni kapısı, Erdaş kapısı, Çimse kapısı,....,Yapulag kapısı, Narende kapısı....Konya'da 11.000 kadar nüfus vardır. Bunlarm 300'ü Ermeni, 50’si Rum(Sille Rumları) her gün Konya'ya ticaret için gelip giderler, diyerek kentin nüfus yapısına ve ticarî mahiyetine de değinir. (A. Erdoğan:1980,s.256; Göyünç, 1998,s. 78)

Konya, konumu ve manevi şahsiyetler açısından tarihi süreçte her daim önem arz etmiştir. Aynı şekilde önemini Osmanlılar döneminde de korurken, Şark seferleri esnasında ordunun uğrak merkezi olma vasfinı idame ettirmiştir. Bilindiği üzere kentlerde ticarî faaliyetler için tesis edilen çarşı, pazar, bedesten ve şehriçi hanları, tüccarlar için korunma, konaklama, beslenme, para kazanma mekânı olarak önem arz etmekteydi.

Konya'ya gelen tüccarlar şehirde Alaaddin Tepesi ile Mevlana Türbesi arasında kalan bölgedeki hanlarda birer oda kiralıyorlardı. (KŞS, nr.39, s.300, h.4,5 H.1113/ M.1700; nr.40,s.27,h.7,H.1114/M.1701))

Anadolu'da hanlar sadece malların el değiştirdiği yerler değil, aynı zamanda kervan bağlantılarının da yapıldığı yerlerdi. Aynı şekilde kervan yolları güzergâhında yer alan kentler arasında yolculuk yapanlar için ve ordunun sefer güzergahında bir uğrak yeri olması dolayısıyla da menzil hanlarının bina edilmesi önem arz etmekteydi(KŞS,nr.42,s.30,h.4,5 H.1116/M.1703;nr.45,s.43,h.6,H.1119/M.1706)

Konya da sahip olduğu menzil hanlarıyla ordu için önemli bir yere sahipti. Nitekim Avusturya ve Rusya Seferleri dolayısıyla sahip olduğu menzil hanlanyla ordunun konaklama, iaşe ihtiyacının temin edilmesi noktasındaki önemiyle Konya'nın adına belgelerde sıklıkla rastlıyoruz. Bunun yanında Hac kervanlan da bu güzergâh üzerinden geçiyor, bu doğrultudaki ticarî ürünler kentte pazarlanma imkanı bulup alıcılarıyla buluşuyor ve kentin ihtiyacı bu suretle gideriliyordu. Hicazdan hareket eden kervanlar Şam-Halep-Ayntab üzerinden 
Konya'ya intikal etmekteydi. Fransa'da bir şövalye olan ve İslam ülkelerini araştırma amacryla 1432'de deniz yoluyla Kudüs'e oradan bir kervanla Anadolu üzerinden Avrupa'ya giden Bertrandon De La Broquiere adlı gezgin, Konya'nın; Karaman ülkesinin en güzel ve büyük şehri olduğunu, ticareti geliştiğini, etrafi sağlam surlarla ve düzgün meyilli hendeklerle çevrili surları kulelerle tahkim edilmiş bir kent olduğunu şehrin bir ucunda küçük bir kale bulunduğunu adet olduğu üzere şehrin ortasında da büyük ve muhkem bir kale bulunduğunu ancak şimdilerde harap halde olduğunu belirtir. (A. Erdoğan,s.;74 Eyice, 1975,s.14)

\section{Ticaret Yolları}

\section{Ulaşım}

Anadolu, tarihî yolların kavşak noktasında kurulmuş bir uygarlık merkezidir. Tarih boyunca önemli bir medeniyet merkezi olan Konya, dünyanın iki eski kıtası olarak kabul edilen Asya ve Avrupa'nın kesiştiği bir yer olan Anadolu'nun ortasında küçük ve büyük çaplı güney-kuzey ve doğu-batı eksenli tarihî geçiş yollarının merkezinde bulunmaktadır. (Darkot:1954,s.842)

Anadolu'daki yol ağını tespit edebilme noktasında bize bilgi veren birtakım kaynaklar bulunmaktadır. Öncelikle seyyahların seyahat güzergâhlan Anadolu yol ağı hakkında bilgi veren önemli bir kaynaktır. Bunun yanında hacıların yol güzergâhı konuya ilişkin tespitte bulunmamızı kolaylaştırmaktadır.

Bir de Osmanlı padişahlarının çeşitli sefer güzergâhları da Anadolu'daki yollar için güvenilir birer kaynak niteliğindedir. Nitekim ele aldığımız şehir bir yol kavşağı hükmündedir.

İstanbul ve Bursa'dan başlayan ve Suriye'ye kadar ulaşan kara yolu, hac seyahatleri yanında sair zamanlarda da ticaret yolu olarak kullanılırdı. Konya ulaşım açısından transit noktasında bulunduğu için Selçuklu Dönemi'nde olduğu gibi Osmanlı Dönemi’nde de önemini korumaya devam etmiştir. Konya, coğrafyanın bahşettiği imkanlara sahip bir şehirdir. Bu yönüyle Konya, tarihî ticaret yollarının kesiştiği ve ticaret mallarının el değiştirdiği önemli tarihî ticaret merkezlerinden biri olma özelliğini korumuştur. Konya, Orta Anadolu steplerinin güneyinde, topografik şartlarının uygunluğu sebebiyle, en eski yol şebekesinin içinde yer almıştır. (Ergenç,s.36.)

Bursa'dan başlayıp Kütahya- Karahisar-Akșehir-Konya-Adana'dan geçerek, Halep ve Şam'a ulaşan bu yol, aynı zamanda Konya'yı başta merkez İstanbul olmak üzere diğer Osmanlı şehirlerine bağlıyordu. Suriye'den Anadolu'ya gelen bir başka ticaret yolunun geçtiği Kayseri, Aksaray üzerinden Konya'ya bağlantılı idi. Osmanlıların, Arap ülkeleri ile münasebetlerini temin ettikleri bir başka yol da, Antalya-Alanya deniz yolu idi. Bu yolun kontrolü Karaman Eyaleti ve dolayısıyla Konya tarafindan yapılıyordu. (Ergenç, 2012,s.31- 32) Orta Çă̆’da Hindistan deniz yolunun keşfi, İpek Yolu ticaretini başka istikamete kaydırdı. Böylece İpek Yolu, Anadolu'dan geçmeyecekti. Konya şehri, Avrupa'dan gelip, Asya'ya giden İpek Yolu üzerindeydi. Bu da Konya şehri gibi, Anadolu'daki diğer ticarî şehirleri de etkilemiştir.(Darkot,s.845.)

Konya, Tarihî İpek Yolu'nun batı kanadını oluşturan Tebriz-İzmir-Istanbul ve hakeza tarihî Baharat Yolu olan İstanbul-İzmir-Şam-Bağdat güzergâhının üzerinde bulunmaktadır. Anadolu'yu çapraz kat eden bu eski yol, Osmanlılar zamanında Bursa'nın iktisadî bir merkez olarak yükselmesinden sonra tali yollarla beslenerek 
büyük bir önem kazanmıştır. (İnalcık, 1960,s.46) Aynca kuzey-güney eksenli tarihî ticaret yolu Sinop’tan başlayarak buradan geçer ve güneyde, Akdeniz sahillerinde Antalya ve Alanya limanları ile Kibris-Misir ve batıdan Doğu Akdeniz'e gelen ticaret yollarnna ulaşır. (O. Turan, 1993,s.358- 363)

Konya, Üsküdar'dan Şam'a kadar uzanan Anadolu'nun sağ kolu üzerinde bulunmaktadır. (Aykut, 1984,s. 198) Bu yol ana yoldur. Bu yol üzerinde tali yollar vardır. Konya-Ankara, Konya-Aksaray-Kayseri, Konya-Alanya, Konya-Karaman-Mut-Silifke tali yolları bulunmaktadır. Konya'ya diğer bir yol da İznikten başlayan ve Pinarbaşı üzerinden gelen yoldur. (Soyucak, 1997,s.17)

Dolayısıyla Konya, her yönden gelen yolların geçtiği transit merkezi idi. Osmanlllar zamanında sağ kol güzergâhında, İstanbul'dan basslayarak Anadolu ve kutsal topraklara doğru devam eden bir hat üzerinde yer almıştır. Osmanlı Devleti'nin haberleşme, ticaret, askerî sefer, hac seferi, devlet memurlarının görev yerlerine salimen ulaşmaları amacıyla belli güzergâhlar üzerinde menziller ve konaklama tesisleri bina ettikleri bilinir. (Çayc1, 2006,s.115)

Bunlardan en önemlileri, yukarıda sözünü ettiğimiz büyük şehirler ve ülkelerarası ticaret yollarına açılmakta ve muhtemelen şehir içindeki yol sisteminin bağlantılı bulunduğu kapılar da bu güzergâha dayanmakta idi. Anadolu'ya gelen hemen her seyyah Konya'ya da uğramış Gez dünyayı gör Konya'yı demiş, dedirtmiştir. Onsekizinci yüzylla gelinceye değin ve sonrasında çok sayıda seyyahın geçiş güzergâhı olan şehir hakkında verdikleri malumat önem arz etmektedir. Bunlardan detaylı bilgi verenlerden birisi olan İbn Batuta, ondördüncü yüzylda şehre uğramış ve ulaşım serüveni şöyle gerçekleşmiştir. Anadolu'ya Lazkiye'den bindiği bir Ceneviz gemisi ile gelmiş, Alanya'da karaya çıkmıştır. Antalya-Burdur-Eğirdir-Gölhisar-Actpayam (Karaağaç), DenizliTavas üzerinden Milas'a geçmiştir. Buradan ise hiçbir güzergâh belirtmeksizin Konya'ya ulaştı̆̆mı belirten seyyah, Konya hakkında bilgiler vermiştir. ( Aykut, 2004,s.37; A. Erdoğan,s.243) Fransız seyyah Pierre Bellon, Filistin ve Suriye üzerinden Anadolu'da ilk olarak Antakya ve İskenderun'u sonra Ceyhan ırmağını, Antik Misis'i geçerek Adana' ya buradan Ereğli ve Konya'ya ulaştı̆̆ııı belirtir. (Bellon:1553,s. 78; A. Erdoğan,s.249)

Fransiz Paul Lucas, 1705-1707 tarihleri arasında Anadolu'ya ikinci seyahatinde Konya'ya uğramıştır. Şehre Karapınar üzerinden eriştiklerini 2000 kişiyi barındıracak konaklama kışlaları bulunduğunu sayısının 4 tane olduğunu belirtir. Şehre gelirken sağda ve solda kasabalar gördüğünü ama bunlara ulaşmak için ana yoldan içeri girmek gerektiğini belirtir. (Lucas:1712,s.38; A. Erdoğan,s.252)

Onyedinci yüzyll sonlarnnda yaşayan Bahri adlı müellif, Üsküdar'dan Şam'a gerçekleştirdiği seyahatinde Konya'ya ulaşım hakkında; "Irişslik Konya'ya 17 günde, 2 gün oturak ittik anda biz" diyerek ulaşımın mesafesi ve konaklama süresi hakkında da bilgi vermiştir. (Coşkun, (-): 15-16) Bu bilgiler ışığında belirli bir sefer güzergâhı bulunduğunu ve bu yola bağlanan tali yollarla tacirlerin Konya üzerinden seferlerini gerçekleştirdiklerine şahit oluyoruz. 


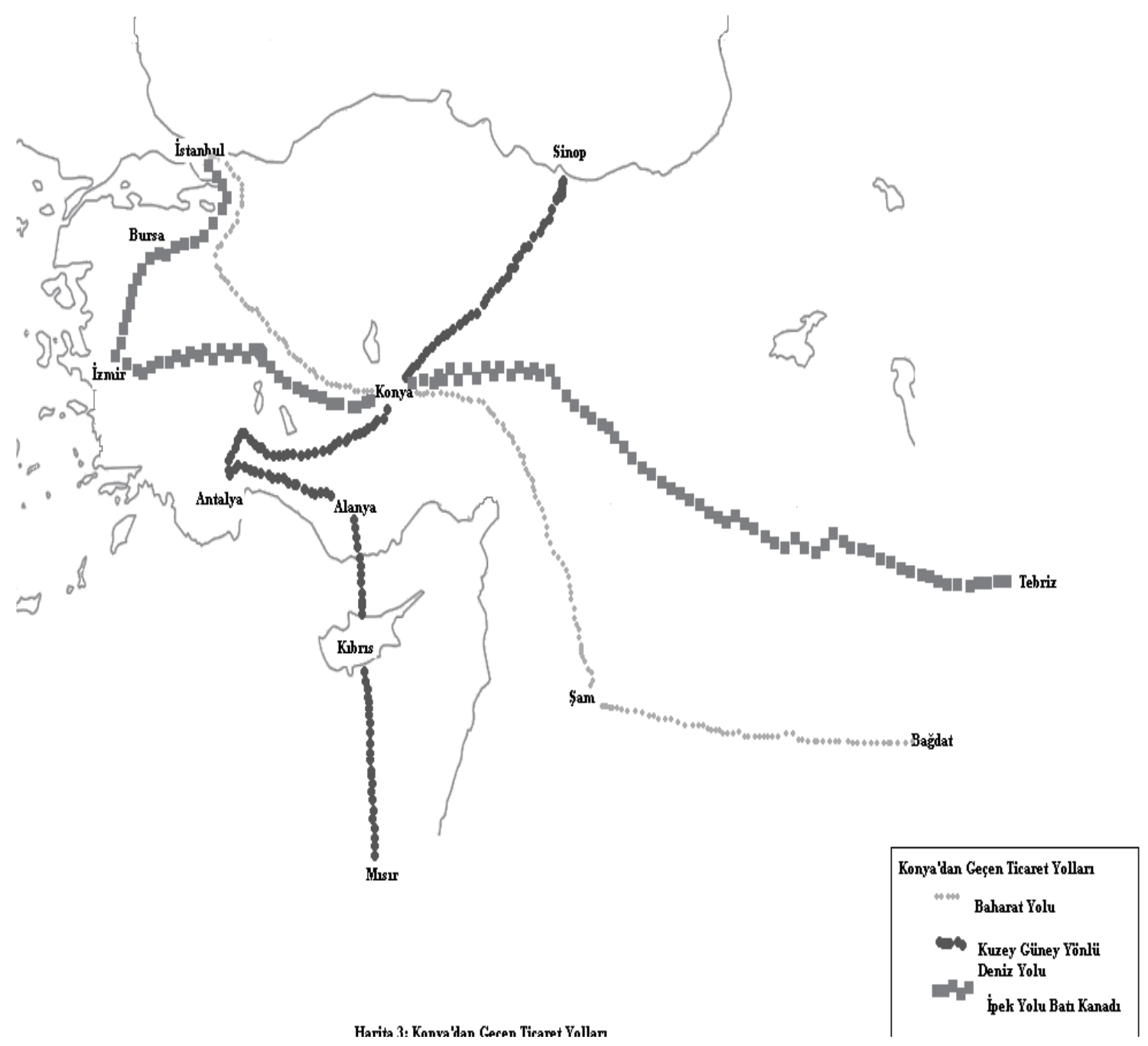

Harita 1: Konya'dan Geçen Ticaret Yolları (Çizen: Rümeysa Bilgili Kars)

\section{Taşımacılık}

Taşımacılık, Anadolu kentlerinde genellikle deve ve katırlarla gerçekleşiriilmekteydi Taşımacılık faaliyetleri sadece tüccar ve yolcuların seyahatlerinde kolaylk sağlamakla kalmıyor, aynı zamanda savaşların yaşandığı süreçte de yöre halkının istifadesiyle temin edilen erzak ve mühimmat nakli ile önem kazanıyordu.

Erzakların toplanma noktaları sefer güzergâhında bulunan kentlerde bina edilmiş olan menzilhaneler aracılığyla temin edilebiliyordu. Menzil, Osmanlılar çağında devletin haberleşmesini sağlamak için kullandıkları ulakların, posta tatarlarının yatmalarn, hayvan değiştirmeleri için yol üzerinde yapılmış, içinde ahır ve yatacak yerlerin bulunduğu tonoz biçiminde binalardır. (Göncü, 1998,s.79) Nakliye hizmetinin, mükarî taifesi olarak bilinen ve kiralama yolu ile taşımacılık yapan kimseler tarafindan yerine getirildiğini söyleyebiliriz. Böylece nakliyat işleri, şehirde belli başlı kimselerin elinde toplanmış ve bir meslek halini almıştır. Bunun yanında Anadolu coğrafyasında taşımacilığın kervanlarla kara yolu güzergâhında yürütüldüğü bilinmektedir. 
Kervan, görünüşte İran menşeli sonradan Araplaşmış bir kelimedir. Ordu veya savaş anlamına gelen “kâr" ile buna gezgin tüccar grubunu ifade eden “-van” son ekinin gelmesinden oluşan bir isimdir. Erzak, eşya veya hayvan konvoylarına da kârbân denilmiştir. Başka bir tanımında ise; kervan, uzak yerlere yolcu veya ticaret eşyası taşıyan yük hayvanı dizisi demekti. (Orhonlu, 1984,s.140; Doğan, 2008,s. 46) Eskiden kara nakliyatıı yapan katar, kafile yerinde kullanılır bir tabirdir. (Pakalın- II, 1983,s.244) Kervan yolları, ticaret yollarının da dağılım yönünü göstermesi açısından önem arz etmektedir.

Ticarî faaliyetlerin yürütülmesi kapsamında Anadolu yol ağı üzerinde tüccar ve yolcuların seyahati açısından bir takım güvenlik önlemleri alınmış, seyahati kolaylaştıracak faaliyetler yürütülmüştür. Bu kapsamda bu seyahatin hangi şartlarda gerçekleştirildiğine değinmemizde fayda vardır. Osmanlı İmparatorluğu'nda sefer, ticaret, haberleşme, yolculuk gibi her türlü ulaşımda hayvan kullanılmaktaydı. Taşımanın hayvanlarla yapıldığı dönemde kervanlar seyahat ve ticaretin başlıca unsuru olmuşlardı. Deve, yola dayanıklılığı ve taşıma gücü bakımından yük hayvanlarının başında gelmektedir.

Deve kervanları, düz arazi ve çöllerde iş görürdü. Dağlık bölgelerde ise katır ve eşek ve daha seyrek olarak atlar kullanılırdı. (Orhonlu,s.35) Kervanlar karışık hayvanlardan meydana geldiği gibi bazı zamanlarda da deve ve katır kafileleri ayrı ayrı teşkil edilirdi. Kervan kafilelerinde yer alan bu yük hayvanlarıyla yolcu ve ticaret malı taşınmaktaydı. Yük, genel olarak bakıldığında nakliye ile bağlanmış çok çeşitli emtia çıkınları için kullanılırdı. Ebadı veya ağırlığı kullanılan yük hayvanının tipine veya nakledilecek emtianın cinsine göre değişirdi. (İnalckk, 1991,s. 9)

$\mathrm{Bu}$ taşımacılık işlemini gerçekleştiren "mükarî,mekkari,mekkare” olarak tabir edilen meslek grubu, tüccarlar için önem arz etmekteydi. Mekkare, nakliyat işlerinde çalıştırllan hayvanlar hakkında kullanılır bir tabirdir. Mekkare, kira hayvanlarına yükletilmiş eşya ve levazım yerine de kullanılırdı. Arapça mükarî kelimesinden bozmadır. Bunun yerine mekari de kullanılırdı. (Pakalın II,s. 451) Mekare, mekari, mekkare kira ile tutulan hayvan, yük hayvanı demektir. (Develioğlu, 2011,s. 700) Mükarî ise mekari, katırcı, kira ile hayvan işleten, demektir. (Develioğlu,s.837) Dolayısıyla şehirler arasında ücret karşılığı tüccar ve yolcuları taşıyan kiralık kervanlara mekkare denilirdi. (Güzelbey, 1962,s. 79)

Ticarî faaliyetlerin yoğun olarak yaşandığı bir coğrafyada var olan Konya, tüccarların ulaşımını sağlama açısından önem arz eden bir konuma sahip bulunmaktaydı. İstanbul'dan güneydeki Osmanlı topraklarına giden yol üzerinde oluşu şehrin gelişmesini de olumlu yönde etkilemiştir. Konya, Anadolu'nun hemen merkezinde ve anayol üzerinde bulunduğundan birçok Osmanlı padişahı seferlere giderken buradan geçmiştir. (Baykara, 2002,s.186- 187) Onsekizinci yüzyllın ilk yarısında Konya, Anadolu'nun büyük sayılabilecek şehirleri arasında yer almaktaydı.

Sefer güzergâhında yer alması, Mevlana Celalaeddin Rumi'nin türbesinin ziyaretgâh olarak önem arz etmesinden de ileri gelmekteydi. Ayrıca yol üzerine konuşlanan menzil, derbent, hanlar seferîlerin ihtiyacına karşıllık verecek şekilde organize edilmekteydi. (tekrar ve doldurma bir parargraf)

Nitekim Konya ve civarındaki mevzilerde kervanların, yolcuların, ulakların güvenli yolculuk 
yapabilmelerini sağlayan konaklama istasyonları hükmündeki menzilhaneler yaptrılmıştır. (Doğan:s.46; Aykut,s.183) Bu menzilhaneler, memurları, elçilerin seyahatinde konaklama, ağıllanma ve korunmasında kullanılmışlardır. Askerî kuvvetlerin konaklama yeri olarak kullanıldığı gibi iaşe ambarı fonksiyonunu da yerine getirmişlerdir.

Bu sayede ordunun sefer sırasında zahire ihtiyacı giderilmiş olmakta idi. Bunun yanında da menziller, seferlerde reayanın malların getirip satabilecekleri bir ticaret merkezi olma hüviyetiyle iktisadî hayata canlllkk kazandırmışlardır. (Aykut,s.184)

Hac Seyahatnamesi yazarlarnndan es-Seyyid Mustafa Niyazi es-Sadi, H.1272/M. 1855 tarihlerinde kaleme aldığ eserinde İstanbul-Mekke arasındaki menzillerden bahsederken Konya menzilleri arasindaki mesafeye de değinmiștir. Akşsehir-Ilgin: 9 saat, Ilgin-Ladik:12 saat, Ladik-Konya: 9 saat, Konya-İsmil: 12 saat, İsmil-Karapınar: 12 saat, Karapınar-Ereğli: 12 saatlik mesafede menzillerin varlı̆ına işaret eder. (es-Seyyid Mustafa Niyazi, 1272,s.16-18) Belirli mesafelerle sefer güzergâhı üzerinde inşa edilen bu kuruluşlar hem güvenlik hem de ekonomik gelir sağlama amacına hizmet etmekteydi.

Osmanlı ordusunun bir veya ihtiyaca göre daha fazla konakladığı sefer menzillerinde devletin ne şekilde zahire ve diğer ihtiyaç maddelerini organize ettiği, günlük ihtiyaçları karşlanması için Orducu esnafinın nasıl bir fonksiyon üstlendiği ve sefer menzillerinde oluşan ekonomik faaliyetin nasıl şekillendiğine değinecek olursak; Osmanlı ordusu sefer için toplandığı sahradan, muharebe sahalarna kadar her gün bir menzil ilerlerken her menzilde ihtiyaca göre konaklamaktadır. Bu mekânlardaki organizasyon, bol emtia, rahat ve huzur seferin neticesine tesir edebilecek kadar önemlidir. Bu miktardaki zahirenin menzilde hazır bulundurulması, aynı zamanda önemli bir nakliye organizasyonunu da gerektiriyordu. Tonlarca hayvan ve insan yiyeceğinin zamanında menzillerde hazır durumda bulundurulması hayati öneme sahipti. (Tekeli, 1971,s.5.)

Sefere çıkacak ordunun çeşitli alanlardaki ihtiyaçlarının karşılanması için bir takım görevlilere ihtiyaç vard. Bunlar genel olarak orducu olarak adlandırlan esnaflardan oluşuyordu. Ordunun levazım hizmetlerini görecek bu kişiler, ülkenin çeşitli bölgelerinden ihtiyaç nispetinde temin edilir ve bu işlerden ilgili yerlerin kadıları sorumlu olur idi. (Türkmen, 2009,s.74) Ordunun ihtiyacının temin edilmesinde durak mahiyetindeki menzillerin önemi apayrı olsa da ihtiyacı gideren Mükarî menzilci taifesinin önemi yadsınamaz bir boyuttadır. İlgili bir ferman, dergah-1 mualla çavuşlarının kentteki ikametleri esnasında iaşelerinin sağlanması talebi hakkındadır. (KŞS, nr. 51, s. 269, h. 3; H. 1141/ M. 1728) Şark Seferi dolayısılla ordunun konuşlandığı Konya menzilinde zahire toplanması hakkındaki bir ferman ile (KȘS, nr. 51, s. 270, h. 1; H. 1141/M. 1728)

Konya menzilinin 3000 esedî kuruşa kiraya verilmesi hakkında başka bir belgede bulunmaktadır. (KȘS, nr. 38, s. 3, h. 1; H. 1112/ M. 1699) Karapınar menzilinin işletmesi ile ilgili taraflar arası bir mesele de bu dolaylarda bulunan bir menzilin varlığnna rastlyyoruz. (KŞS, nr. 57, s. 40, h. 1; H. 1162/ M. 1750)

Sefer-i Hümayun için hazırlı yapılması hakkında bir ferman yollanan Konya'da Konya valisi Mustafa Paşa'ya hitaben, İran canibine gerçekleştirilecek sefer için Ilgm ve Keçiborlu ve Gönen ve Eğridir kazalarnndan Ilgin menziline nakil ve mevcud ettirilmesi gereken arpa, saman talebi söz konusudur. (KŞS, nr. 57, 


\section{s. 159 , h. 1; H. 1162/M. 1750)}

Ilgın'da bulunan başka bir menzilin varlığına şahit olduğumuz belgede miktarı belirtilen zahirenin sefer öncesi ilgili kazalardan tedarik edilip Ilgın'daki menzilde hazır bulundurulması emrolunmuştur.

Sefer için mühimmat naklini gerçekleştirecek yük hayvanlarına olan ihtiyacın da Konya'dan karşılandığını örnekleyen bir belgede; Tiflis taraflarına gönderilecek sefain ile Trabzon'a gönderilecek cephane ve tophane mühimmatı ve zahire türleri Trabzon İskelesi'ne dahil olduktan sonra mükarî develeriyle karadan naklettirmek için Karaman Eyaleti’ne vaki kazalardan 750 mükarî deve kiralanması istenilmiş, her biri için 30 kuruş mübaşir YusufAğa eliyle deve sahiplerine teslim edilmiştir. (KŞS, nr. 49, s. 173, h.1; H. 1130/ M. 1718)

Rusya ile bu dönemde Osmanlı Devleti'nin arasında devam eden savaşlarda sefer güzergâhlarından yük hayvanlarının tedarik edildiğini öğreniyoruz. İlgili başka bir belge ise; Moskov keferesi üzerine yapılacak sefer amacıyla istenen mükarî develer için sefer güzergâhında yer alan Konya'dan her res' deveye 43'er kuruşdan 250 kuruş bedelin Deve Ağası'na teslim olunduğu hakkındadır. (KŞS, nr. 53, s. 1, h. 7; H. 1149/ M. 1737)

Konya'da bu türden hayvan kiralama işlemlerine o kadar sıklıkla rastlanmaktaydı ki halkın mükarîlik adını verdikleri bir meslek kolu geliştirmişler ve bu yolla önemli ekonomik gelir temin etmişlerdir. Sefer için Konya'dan talep olunan 358 adet mükarî deve Kaza-i Konya, Larende, Erikli, Eskiil, İnsuyu, Turgud, Gaferyad, Aladağ, Kaza-i Türkmenan-1 Bozulus'tan tedarik olunmasina dair (KŞS, nr. 54, s. 5, h. 2; H. 1151/ M. 1739) bu belgede adı geçen civardaki ahalinin mükarîlik adı verilen meslek grubu mensupları olduğu çıkarımında bulunabiliriz.

Aynı şekilde bu dolaylarda yer alan geniş otlaklar yük hayvanlarının yetiştirilmesinde önemli bir etken olmalıydı. Nitekim taşımacılığın mükarîler aracılığıyla gerçekleştirildiğini biliyoruz. Konya'da sefer için bu taifelerden at, deve kiralandığına dair belge ömeklerinden bahsettik. Bunun yanında tüccarların kervanlar halinde uğradıkları kentte taşımacıııta yine bu işle uğraşan zümrelerden istifade ettikleri de aşikârdır. Beygir fiyatları tüccarların taşımacıllk işlemleri esnasında 1119/1707'de 20 kuruş olarak belirtilmektedir. (KŞS, nr. 43, s. 76, h. 3; H. 1119/M. 1707)

Tüccarlar zaman zaman kendi imkanlarıyla taşımacılık işlevini yürütmekteydiler. Kafile halinde yolculuk yapmanın daha emniyetli olduğu düşünülerek kendi yük hayvanlarıyla bu kafilelerde yer alan tüccarlara rastlıyoruz. $\mathrm{Bu}$ taifelerden istifadeyle taşımacılık yapıldığını ömekleyen bir belgede; Mustafa ibn-i Hasan Ağa'nın kölesi Abdullah ve mükarî taifesinden Bekir; Aslen Bursa'da yaşayan Diyarbekirli Mustafa'nın, ticaret eşyasını kendi develerine yükleyip mükarî eşliğinde Konya'ya getirme niyetindeydiler. (KŞS, nr. 41, s. 55, h. 1; H. 1116/M. 1704)

Konya-İzmir arasında ticar̂̂ anlamda bir hareketliliğin söz konusu olduğunu ${ }^{3}$ bu güzergâhta yolculuk

\footnotetext{
${ }^{3}$ Bu konuya ilişkin daha detaylı bilgi için bkz: Rümeysa Bilgili, Şer'iyye Sicilleri’ne Göre Osmanh İmparatorluğu'nda İç Ticaret Ankara-Konya-Ayntab Örneği: (1700-1750), Nevşehir Hacı Bektaş Veli Üniversitesi, Sosyal Bilimler Enstitüsü, Tarih Anabilim Dal, Doktora Tezi, Nevşehir 2017.
} 
yapan mükarînin varlığından da öğreniyonuz. Şöyle ki, es-Seyyid Mehmet adlı şahıs devecilik mesleğiyle uğraşmaktadır. İzmir'e gidip gelmesi esnasında kervanında yer alan Konyalı es-Seyyid Ali'den taşıma bedeli olarak kalan 12 kuruşluk borcunu talep etmektedir. (KŞS, nr. 53, s. 84, h. 2; H. 1149/ M. 1737)

Halep-Konya arasındaki irtibat hakkında bilgi edindiğimiz ve bu güzergâhta da mükarîlerden istifade edildiğini örnekleyen bir belge; Halep’te Harem köyünden mükarî el-Hac Murat ibn-i el-Hac Kasım'ın; Konyalı el-Hac Şaban ibn-i Veli ile aralarında geçen bir taşıma bedeli hakındadır. Söz konusu taşıma olayı, Halep’te başlamış Konya güzergâhında son bulmuştur. Halep’ten Konya’ya gittiklerinde her kantarına 9 kuruş vermek üzere Şaban, 7 kantar yükünü kardeşi Ahmet ile mükarî el-Hac Murat'ın davarlarına yükleyip yola çıkmışlardır. Konya'ya geldiklerinde Şaban ile aralarında yaptıkları yeni bir anlaşma gereği taşıma bedeli olarak 8,5 kuruşluk 1 bütün ve 1 yarım sarı̆ğ el-Hac Murat'a vermiş ve böylece aralarında sulh edilmiştir.

Şaban'ın 7 kantar yükünü 8,5 kuruştan kafiledeki diğer yolculardan da el-Hac Mehmet'in 3 yükünü ve Mahmut ibn-i el-Hac Mehmet'in 3 yükünün kiralarını aynı bedel üzerinden tamamen kendilerinden aldığı ve alacağının kalmadığı hakkında bilgi ihtiva etmektedir. (KŞS, nr. 39, s. 100, h. 3; H. 1113/ M. 1701)

İzmir-Konya arasında gerçekleştirilen ticarî ürün nakliyatında da mükarîlerden istifade edildiğini belirtmiştik. İlgili bir belgede bu güzergâhta Yemen'den getirilen kahvenin ülke içerisine naklinin İzmir üzerinden Konya yönünde gerçekleştirildiğini saptayabilmekteyiz. Konya Kasap Sinan Mahallesi'nden es-Seyyid Mustafa ibn-i Mehmet, deveci taifesinden Asayir Türkmen Cemaati'nden olan Kel Ali ibn-i Abdi'nin develerini İzmir'den Konya'ya belirli bir miktardaki eşyanın nakli için kullanmıştır. Uşak kazasında Cafer Ağa Sarayı adlı mahalde esSeyyid Mustafa'nın izni olmadan Ali, arkadaşlanı İbrahim, Mehmet, Vasıl, Hüseyin ile 103 vukiyelik Yemenî kahveyi zayi etmişlerdir.

Zayi olan kahve bedelinin es-Seyyid Mustafa'ya teslim edilmesi hususunda Ali, uyarılmıştır. (KŞS, nr. 57, s. 63, h. 4; H. 1162/ M. 1750)

Mükarîlerin aynı zamanda köle ticaretiyle uğraştıkları da bilinmektedir. Aynı zamanda Mısır'dan İstanbul'a yapılan hazinenin naklinin Konya üzerinden mükarîler aracılığıyla gerçekleştirildiğini örnekleyen başka bir belgede; Misır'dan İstanbul'a giden hazine-i hümayun kafilesinden es-Seyyid Ebubekir Çavuş, Konya'dan katırcı taifesinden Arap Ali ibn-i Abdi arasında gerçekleşen bir olayda Ali, Humus kasabasında hizmet ederken aynı zamanda köle ticaretiyle de uğraşmaktadır.

İstanbul'da bulunduğu esnada Abdullah adlı köleyi Ebubekir Çavuş'a 60 kuruşa satmıştır. Ancak Abdullah bir süre sonra firar etmiş ve Ebubekir Çavuş'un malından 41 kuruş, 1 rub‘ kıymetli altın kakmalı ve sim kakmalı 2 adet fitilli tüfengi çalarak yeniden Arap Ali kafilesiyle Konya’ya hareket etmiştir.(KŞS, nr. 57, s. 52, h. 4; H. 1162/M. 1750)

Taşımacılık faaliyetinin kervan halinde gerçekleştirildiğini ve güvenliğine de ayrı bir ehemmiyet verildiğini, güven duyulmayan kişilerin kervana dahil edilmediğini örnekleyen bir belgede; Adana'dan Konya'ya giden bir kervana sonradan katılmak isteyen Arab Ömer ibn-i Abdullah, Mehmet Ağa mübaşeretiyle, Hacı 
Mehmet ibn-i Ali, Molla Ahmet ibn-i Hacı Mustafa, Hacı Mehmet ibn-i Süleyman ile bir anlaşmazlık yaşamışlardır. Arab Ömer, "Davadan 8 gün önce Karapınar kazasında bu şahislar kervan olmuş giderken ben yanlarına vardığımda bana bu şahıs hırsız casusudur dediler, at- besat ve malıma zarar verdiler." diyerek sulh için 75 kuruş talep etmiştir. Kendisine bu bedelin ödenmesi üzerine anlaşmazlık son bulmuştur. (KŞS, nr. 53, s. 125, h. 3; H. 1149/M. 1737 )

Konya, Hac yolculukları açısından da önemli bir konumda bulunuyordu. Konya Arapları, çöl şartlarını bilen kişiler olduklarından hacca gidecek olan şahısları belli bir ücret karşılığı develeriyle götürüp getirirlerdi. Arap el-Hac Süleyman ibn-i Abdullah, bu işi kendisine ait 19 deve ile yapıyordu. (KŞS, nr. 52, s. 34, h. 3; H. 1142/ M. 1730) Üsküdar'dan Şam-1 şerif'e varıp gelinceye kadar yol üzerindeki hacıların muhafazası hakkında kent yetkililerine bir ferman yollandığını başka bir belgeden öğreniyoruz. (KŞS, nr. 57, s. 148, h. 1; H. 1162/ M. 1750) Konya'ya böyle bir ferman suretinin gönderilmiş olması, şehrin hac, hacılar ve hac ticareti açısından önemli olduğunu gösterir. Hac güzergâhı, Konya'dan başladığında Adana-Ayntab-Halep-Şam-Hicaz olarak devam etmekteydi. Bu durum Konya ve Ayntab kentlerinin hac güzergâhı niteliğiyle de ortak özelliğe sahip olduğunu göstermesi açısından önem arz etmektedir.

Bu güzergâhı takip etmemize imkân tanıyan bir vesika, Konya'da Müsski Mahallesi'nden olup hac dönüşü esnasında Şam'da vefat eden el- Hac Mehmet ibn-i el-Hac Ahmet'in ölmeden önce vasi tayin ettiği elHac Mustafa aracılığıyla mallarının varislerine teslim olunması hakkındadır. (KŞS, nr. 51, s. 130, h. 2; H. 1140/ M. 1728

\section{Sonuç}

Konya, Anadolu'nun önemli kentlerinden birisidir. Bu önemi kazanmasının amilleri onun sahip olduğu niteliklerinden ileri gelmektedir. Kervan taşımacılığının revaçta olduğu dönemlerde ticaret yollarının bu güzergâhtan da geçtiğini saptamış bulunmaktayız. Bu durum kentin ekonomik kalkınmasına katkı sağlamakla birlikte halkın bu alana ilişsin meslek kolları şeklinde de örgütlenmelerinde etkili olmuştur. Nitekim mükarilik öncelikle ordu için taşıma hayvanı yetiştirme esasına dayanırken aynı zamanda tüccar ve yolcular için de taşıma vasıtası olması hasebiyle teşkilatlanmanın temeli olmuştur. Ordu için gereken hayvanların menzil denilen konaklama merkezlerinde daha önceden bulundurulması gereği fermanlarla mükarilere bildirilmekte ve bu ihtiyaç Konya mükarilerince karşılanmaktaydı. Tüccarların da nakil ihtiyacının karşılanması noktasında bu hayvanlar kiralanarak ya da satın alınarak ihtiyaç giderilmiştir.

Kent hac güzergahında da yolcuların ve ticaretin idamesinde öneme sahip bulunmaktaydı. Tüm bu hususlar kentin ulaşım ve taşımacılığı yanında yolcuların ve tüccarların güvenliğini sağlama noktasında da gereken önlemleri alacak mahiyette dizayn edildiğini göstermektedir. 
ISSN: $2667-4432$

Journal of Universal History Studies (JUHIS) • 2(2) • December• 2019 • pp. 296-307

\section{Kaynakça}

[1] Konya Şer'iye Sicilleri, 39- 40- 41- 42- 43- 44- 45- 46- 47- 48- 49- 50- 51- 52- 53-54- 55- 56- 57 nolu defterler

[2] Aykut N (1984) IV.Murat'nn Revan Seferi Menzilnâmesi, İstanbul Üniversitesi Edebiyat Fakültesi Dergisi,S.34,İstanbul:183-246)

[3] Barthold W (1984) İslam Medeniyeti Tarihi, 6.Basım, Düzenleyen: M.Fuat Köprülü, (Diyanet işleri Başkanlığı Yayınları, Ankara)

[4] Baykara T (2002) Konya, Türkiye Diyanet İslam Ansiklopedisi,(Türkiye DiyanetVakfi Yayınlan, İstanbul: 182-187)

[5] Bellon P (1553) Les observations de plusteurs singularites et choses mémorables trouvées en Grèce, Asie, Judée, Égypte, Arabie et autres pays estranges, Paris.

[6] Coşkun M (-) Bahri Üsküdar'dan Şam'a Kadar Konaklar, Süleymaniye Kütüphanesi, Mihrişah Sultan,322/5,15:15-16

[7] Çaycı A (2006) Osmanlı Seyyahlarının İzlenimleriyle Konya ve Çevresi, Selçuk Üniversitesi İlahiyat Fakültesi Dergisi, S.21, Konya:114-147)

[8] Darkot B (1954) Konya, İslam Ansiklopedisi, C.VI, (Milli Eğitim Bakanlığı Yayınları, İstanbul:841-853)

[9] Devellioğlu F (2011) Osmanlıca-Türkçe Ansiklopedik Lügat, (Aydın Kitabevi, Ankara)

[10]Doğan İ.B (2009) Tarih Öncesinde Ticaret ve Değiş Tokuş, (Arkeoloji ve Sanat Yayınları, İstanbul)

[11]Erdoğan A(1936) Kitabelerin Değeri ve Konya, Konya/ S.4,Konya: 221-225)

[12]Erdoğan A(2001) Gez Dünyayı Gör Konyayı, (Yapı Kredi Vakfi Yayını, İstanbul)

[13]Ergenç Ö (2012) XVI. yy’da Ankara ve Konya, (Tarih Vakfi Yurt Yayını, İstanbul)

[14] es-Seyyid Mustafa Niyazi es-Sadi (1855) Menasik-i Hacc-1 Şerif, Süleymaniye Kütüphanesi, Basma No:3120/1,ístanbul.

[15]Eyice S (1975), Bertrandon de la Broquiére ve Seyahatnamesi İslam Tetkikleri Enstitüsü Dergisi, VI/1-2.

[16]Göncü K (1988) Gaziantep, Gaziantep Ticaret ve Sanayi Odası, (Gaziyurt Matbaacılık, Gaziantep)

[17]Göyünç N (1998) Niebuhr ve 1766 Sonlarında Konya, Yeni İpek Yolu Konya Ticaret Odası Dergisi, Konya I/Mayıs, edit:Y. Küçükdağ, (Damla Ofset,Konya)

[18]Güzelbey C.C (1962) Gaziantep’te Kervancılık, GKD-V/Nisan:79-94.

[19]İnalckk H (1960) Bursa-I, XV. Asır Sanayi ve Ticaret Tarihi Vesikalar, Belleten 24/93:(46-101)

[20]İnalcık H (1991) Osmanlı İpek Ticareti-Madencilik ve Ziraatinde Yük(Himl),çev. Eşref Bengi Özbilen, 306 
Türk Dünyası Araştırmalan Dergisi,(S.75:9-29)

[21]Lucas P (1712) Voyage du Sieur Paul Lucas fait par ordre dur oy dans la Greece l'Asie Mineure,la Macedoine et l'Afrique, I.Cilt, Paris, eds.Nicolas Simart, MDCCXII.

[22] Orhonlu C (1984) Osmanlı İmparatorluğunda Şehircilik ve Ulaşım Üzerine Araştırmalar, (Ege Üniversitesi Edebiyat Fakültesi Yayınları,İzmir)

[23]Pakalın M.Z (1983) Osmanlı Tarih Deyimleri ve Terimleri Sözlüğü-I-II-III,(Milli Eğitim Basımevi, İstanbul)

[24]Soyucak A.R (1997) Konya ve Çevresinde Eşkıyalık Hareketleri (1640-1675), Yüksek Lisans Tezi, Selçuk Üniversitesi, Sosyal Bilimler Enstitüsü, Tarih Anabilim Dalı, Yeniçağ Tarihi Bilim Dalı, Konya.

[25]Tekeli İ (1971) Osmanlı İmparatorluğu'nda Mekân Organizasyonundaki Gelişmeler, Belgelerle Türk Tarihi Dergisi, S.45,(Ankara)

[26]Turan O (1993) Selçuklular Tarihi ve Türk İslam Medeniyeti, (Boğaziçi Yayınları, İstanbul)

[27]Türkmen M.N (2009) XVII.Yüzyıl Sefer Menzillerinin Ekonomik Yönü ve Esnafin Katkısı, http://dergiler.ankara.edu.tr/dergiler/18/30/218.pdf.(10 Nisan 2015) 